\title{
Profitability and Efficiency of Red Onion Farming
}

\author{
Imron Rosyadi, Didit Purnomo
}

Faculty of Economics and Business, Universitas Muhammadiyah Surakarta, Jalan A. Yani Tromol Pos 1 Pabelan Kartasura Surakarta 57102, E-mail: imron@ums.ac.id

\begin{abstract}
The purpose of this research is to determine and analyze the profitability and performance of onion farming marketing margins; analyze and know the parts of prices received by farmers and analyze the efficiency of onion farming in the district of Brebes. Samples taken in this study is 30 onion farmers in the district of Brebes, who settled in six villages, each village was taken 5 farmers as the research sample. These results indicate that the location of onion farming research does not provide benefits significantly to the household economy of farmers. Higher selling prices at the retail level and supermarkets do not have a significant impact on the level of profits of farming in the study area. Farming is done by farmers in the study area is inefficient. Onion marketing chain in the study area is relatively long, which consists of 4 lines of marketing.
\end{abstract}

Keywords: farming, profitability, efficiency, input-output

JEL classification: Q1

\section{Profitabilitas dan Efisiensi Usahatani Bawang Merah}

\begin{abstract}
Abstrak
Tujuan penelitian ini menentukan dan menganalisis profitabilitas dan kinerja margin pemasaran pertanian bawang; menganalisis dan mengetahui bagian dari harga yang diterima oleh petani/ saham petani) dan menganalisis efisiensi pertanian bawang di Kabupaten Brebes. Sampel yang diambil dalam penelitian ini adalah 30 petani bawang di Kabupaten Brebes, yang menetap di enam (6) desa, setiap desa diambil 5 petani sebagai sampel penelitian. Hasil penelitian menunjukkan bahwa lokasi penelitian pertanian bawang tidak memberikan manfaat signifikan (menguntungkan) terhadap ekonomi rumah tangga petani. Harga jual yang lebih tinggi di tingkat eceran dan supermarket tidak memiliki dampak yang signifikan pada tingkat keuntungan pertanian di daerah studi. Pertanian bawang yang dilakukan oleh petani dalam wilayah penelitian, tidak efisien. Jaringan pemasaran bawang di daerah penelitian relatif lama, yang terdiri dari 4 jalur pemasaran.
\end{abstract}

Kata kunci: usahatani, profitabilitas, efisiensi, output-input Klasifikasi JEL: Q1

\section{Pendahuluan}

Kabupaten Brebes merupakan salah satu kabupaten di Provinsi Jawa Tengah, Indonesia. Luas wilayahnya $1.657,73 \mathrm{~km}^{2}$, jumlah penduduknya sekitar 1.767.000 jiwa (2003). Ibukotanya adalah Brebes. Brebes merupakan kabupaten dengan jumlah penduduk paling banyak di Jawa Tengah. Kabupaten Brebes terletak di bagian barat Provinsi Jawa Tengah, dan berbatasan langsung dengan wilayah Provinsi Jawa Barat. Ibukota kabupaten Brebes terletak di bagian timur laut wilayah kabupaten. Kota Brebes bersebelahan dengan Kota Tegal, sehingga kedua kota ini 'menyatu'.

Ibukota Kabupaten Brebes terletak sekitar $177 \mathrm{~km}$ sebelah barat Kota Semarang, atau $330 \mathrm{~km}$ sebelah timur Jakarta. Kabupaten ini dilalui jalur pantura, dan menjadi pintu masuk utama Jawa Tengah di sisi barat dari arah Jakarta/Cirebon, sehingga Brebes memiliki posisi yang cukup strategis. Selain itu, juga terdapat jalan provinsi sebagai jalur alternatif 


\section{Jurnal Ekonomi Pembangunan, 15 (2), Desember 2014, 117-127}

menuju ke kota-kota di Jawa Tengah bagian selatan seperti Purwokerto, Kebumen, dan Yogyakarta. Brebes merupakan kabupaten yang cukup luas di Provinsi Jawa Tengah. Sebagian besar wilayahnya adalah dataran rendah. Bagian barat daya merupakan dataran tinggi dengan puncaknya Gunung Pojoktiga dan Gunung Kumbang; sedang bagian tenggara terdapat pegunungan yang merupakan bagian dari Gunung Slamet, beriklim tropis, dan curah hujan rata-rata $18,94 \mathrm{~mm}$ per bulan. Kondisi itu menjadikan kawasan tersebut sangat potensial untuk pengembangan produk pertanian, khususnya bawang merah.

Bawang Merah bagi Kabupaten Brebes merupakan trademark mengingat posisinya sebagai penghasil terbesar komoditi tersebut di tataran nasional serta memilki brand image yang baik bagi konsumen bawang merah di Indonesia. Bawang merah Brebes terkenal dengan kualitas yang lebih baik dari bawang merah yang berasal dari daerah lain di Indonesia atau luar negeri seperti, Thailand dan China. Bawang merah asli Brebes memiliki cita rasa tinggi, yaitu lebih menyengat dan harum serta produk jadi (bawang 'goreng')-nya lebih enak dan 'gurih'. Bawang merah merupakan salah satu produk andalan dan unggulan sektor industri Kabupaten Brebes. Hal ini ditegaskan dalam Peraturan Daerah Kabupaten Brebes Nomor 8 tahun 1986 bahwa lambang daerah dalam bentuk bulat telur serta gambar bawang merah melambangkan bahwa telur asin dan bawang merah merupakan hasil spesifik daerah Brebes (Pemkab Brebes, 2008)

Produksi bawang merah di Kabupaten Brebes dari tahun ke tahun mengalami peningkatan. Pada tahun 2007 sebesar 159.342,6 ton, awal tahun 2008 meningkat menjadi 179.227,8 ton (Bappeda Brebes, 2008). Sementara harga bawang merah cenderung berfluktuatif, pada awal 2007 harga bawang merah sebesar $7.000 / \mathrm{kg}$, pada awal tahun 2008 turun menjadi $6.000 / \mathrm{kg}$, pada pertengahan tahun 2008 naik kembali menjadi 10.000/kg (BPS Brebes, 2008). Fluktuasi harga bawang merah menjadi salah satu penyebab berkurangnya keuntungan petani bawang merah di Kabupaten Brebes. Fluktuasi harga bawang merah disebabkan terjadinya over supply akibat panen raya atau masuknya bawang merah impor (Agustian et al., 2005). Penyebab yang lain secara berurutan adalah fluktuasi harga pupuk, fluktuasi harga obat-obatan, fluktuasi harga bibit, produksi turun akibat iklim dan produksi turun karena HPT (Nurasa dan Darwis, 2007; Agustian et al., 2005; Saptana, et al., 2006).

Hasil analisis usahatani bawang merah di Kabupaten Brebes oleh Nurasa dan Darwis (2007) menunjukkan bahwa produksi yang dihasilkan dari usahatani bawang merah cukup tinggi yaitu mencapai 11,1 ton/ha dalam satu tahun dengan nilai yang diperoleh sebesar Rp70.892.000. Sementara keuntungan yang diperoleh dalam satu tahun atau dua kali tanam hanya sebesar Rp6.831.000, dengan R/C rasio sebesar 1,1. Selanjutnya Nurasa dan Darwis (2007) memberikan kesimpulan bahwa berusahatani bawang merah telah dapat memberikan keuntungan, akan tetapi menurut para petani tingkat keuntungan yang diperoleh belum cukup untuk dapat memenuhi kebutuhan ekonomi rumah tangga petani.

Perolehan keuntungan yang kecil oleh petani disebabkan tingginya biaya produksi (output) yaitu $90 \%$ dari total pendapatan serta disebabkan oleh fluktuasi harga output sebesar $33,33 \%$, fluktuasi harga pupuk sebesar $28,57 \%$, flutuasi harga obat-obatan $55,56 \%$, fluktuasi harga bibit, iklim dan hama pascatanam (Nurasa dan Darwis, 2007; Agustian et al., 2005; Saptana, et al., 2006). Sehingga dapat dirumuskan permasalahan, bagaimana struktur pendapatan (kinerja profitabilitas) dan kinerja margin pemasaran usahatani bawang merah di Kabupaten Brebes?; bagaimana struktur bagian harga yang diterima petani (farmer's share) di Kabupaten Brebes? dan apakah usahatani bawang merah di Kabupaten Brebes sudah dilakukan secara efisien?

Tujuan dilaksanakannya penelitian ini adalah untuk mengetahui dan menganalisis profitabilitas dan kinerja margin pemasaran usahatani bawang merah di Kabupaten Brebes; menganalisis dan mengetahui bagian harga yang diterima petani (farmer's share) di kabupaten Brebes dan menganalisis efisiensi usahatani bawang merah di Kabupaten Brebes.

Perkembangan produksi beberapa komoditas sayuran ditampilkan pada tabel 1 , yang memberikan beberapa gambaran sebagai ber- 


\section{Jurnal Ekonomi Pembangunan, 15 (2), Desember 2014, 117-127}

ikut: (1) Pada periode sebelum krisis ekonomi (1986-1997), semua komoditas sayuran unggulan, yaitu bawang merah, kentang, kubis, tomat dan cabe merah, mengalami pertumbuhan produksi positif yang cukup tinggi, yaitu masing-masing tumbuh 7,82 persen, 0,82 persen, 7,98 persen, 17,69 persen dan 34,11 persen per tahun; (2) Pada periode setelah krisis ekonomi (1997-1999), semua komoditas sayuran unggulan, yaitu bawang merah, kentang, kubis, tomat dan cabe merah, juga masih tetap tumbuh cukup cepat yaitu masing-masing 22,75 persen, 7,65 persen, 4,34 persen, 10,8 persen dan 12,29 persen per tahun; dan (3) Pada periode 2000-2002, semua komoditas sayuran unggulan, yaitu bawang merah, kentang, kubis, tomat dan cabe merah menunjukkan kinerja yang berbeda antarkomoditas. Komoditas yang tetap tumbuh positif cukup tinggi adalah kubis yaitu 6,23 persen per tahun. Komoditas yang mengalami stagnasi adalah bawang merah, tomat dan cabe merah yang tumbuh sekitar $0-0,56$ persen per tahun, sedangkan komoditas yang mengalami penurunan produksi adalah wortel (-5,56\%/tahun).

Hasil kajian Saptana et al. (2001) di Kabupaten Karo dan Simalungun mengungkapkan bahwa penurunan produksi pada periode terakhir ini lebih disebabkan oleh faktor eksternal (di luar petani), seperti ketidakstabilan sosial politik dan keamanan dalam negeri, yang menyebabkan tersumbatnya ekspor ke Singapura dan Malaysia sebagai akibat dari kehilangan kepercayaan pembeli di negara-negara tersebut. Hal tersebut terkait erat dengan dayabeli masyarakat dan cakupan tujuan pasarnya. Komoditas kubis tetap tumbuh positip karena harganya yang relatif terjangkau pembeli dan memiliki tujuan pasar yang luas, sedangkan harga cabe merah dan tomat sangat mahal dan jangkauan pasarnya terbatas pada pasar lokal dan regional.

Hal ini diperkuat oleh hasil kajian Saptana et al. (2001) di Jawa Tengah, yang menunjukkan penurunan produktivitas pada cabe merah dan tomat disebabkan antara lain

Tabel 1. Perkembangan Produksi Sayuran Menurut Jenis di Indonesia, Tahun 1986-2002 (Ton)

\begin{tabular}{|c|c|c|c|c|c|c|c|}
\hline Tahun & $\begin{array}{c}\text { Bawang } \\
\text { merah }\end{array}$ & Cabe & Kentang & Kubis & Tomat & Wortel & Ketimun \\
\hline 1986 & 382.117 & 439.000 & 446.295 & 949.357 & 165.000 & 108.408 & 293.000 \\
\hline 1987 & 412.522 & 436.189 & 368.961 & 978.514 & 187.430 & 132.229 & 267.976 \\
\hline 1988 & 379.380 & 449.000 & 418.154 & 771.273 & 192.200 & 132.387 & 307.000 \\
\hline 1989 & 399.488 & 518.000 & 559.396 & 926.110 & 238.202 & 192.559 & 324.386 \\
\hline 1990 & 495.183 & 417.000 & 628.727 & 1.071 .756 & 207.546 & 172.200 & 255.156 \\
\hline 1991 & 509.013 & 425.000 & 525.839 & 974.553 & 235.285 & 172.727 & 268.201 \\
\hline 1992 & 528.311 & 440.000 & 702.584 & 1.213 .360 & 228.726 & 233.470 & 268.436 \\
\hline 1993 & 561.267 & 350.000 & 809.457 & 1.266 .040 & 226.208 & 192.482 & 418.000 \\
\hline 1994 & 636.864 & 316.915 & 877.146 & 1.417 .980 & 301.723 & 234.178 & 530.000 \\
\hline 1995 & 592.544 & 1.589 .978 & 1.035 .260 & 1.904 .207 & 652.045 & 247.179 & 631.326 \\
\hline 1996 & 768.560 & 1.043 .792 & 1.109 .560 & 1.829 .121 & 591.597 & 269.837 & 614.381 \\
\hline Trend (\%) & 7,82 & 34,11 & 10,82 & 7,98 & 17,69 & 11,13 & 9,45 \\
\hline 1997 & 605.736 & 801.832 & 813.368 & 1527101 & 460542 & 227322 & 489.595 \\
\hline 1998 & 599.304 & 848.524 & 998.032 & 1660379 & 547257 & 332846 & 506.889 \\
\hline 1999 & 938.293 & 1.007 .726 & 924.058 & 1659507 & 562406 & 286536 & 431.950 \\
\hline Trend(\%) & 22,75 & 12,29 & 7,65 & 4,34 & 10,8 & 16,25 & $-5,63$ \\
\hline 2000 & 772.880 & 727.747 & 977.349 & 1.336 .410 & 593.392 & 326.693 & 423.282 \\
\hline 2001 & 774.562 & 580.464 & 831.140 & 1.205 .404 & 483.991 & 300.648 & 431.921 \\
\hline 2002 & 766.572 & 635.089 & 893.824 & 1.232 .843 & 573.517 & 282.248 & 406.141 \\
\hline 2003 & 762.795 & 1.066 .722 & 1.009 .979 & 1.348 .433 & 657.459 & 355.802 & 514.210 \\
\hline 2004 & 757.399 & 1.100 .514 & 1.072 .040 & 1.432 .814 & 626.872 & 423.722 & 477.716 \\
\hline Trend (\%) & $-0,56$ & 14,98 & 3,85 & 2,56 & 4,10 & 5,21 & 3,89 \\
\hline
\end{tabular}




\section{Jurnal Ekonomi Pembangunan, 15 (2), Desember 2014, 117-127}

oleh: (1) Menurunnya penggunaan bibit berkualitas, khususnya kentang; (2) Perluasan areal lahan dengan merambah areal hutan sejak terjadinya krisis ekonomi; (3) Terjadinya penurunan kesuburan tanah karena erosi berat pada lapisan top soil yang disebabkan oleh banjir, sebagai akibat perambahan hutan di Pegunungan Dieng; dan (4) Degradasi tingkat kesuburan lahan, karena tidak diterapkannya sistem usahatani konservasi, dimana baris tanaman tidak mengikuti garis kontur tetapi mengikuti garis lereng.

Secara administratif Kabupaten Brebes terbagi dalam 17 kecamatan, yang terdiri atas 292 desa dan 5 kelurahan. Dalam Pola Perwilayahan Provinsi Jawa Tengah, Kabupaten Brebes termasuk Wilayah Pembangunan II dengan pusat di Tegal. Kabupaten Brebes sendiri dalam perwilayahan pembangunan dibagi menjadi 3 Sub Wilayah Pembangunan (SWP) yaitu:

a) SWP Ia, dengan pusat di Brebes, meliputi Kecamatan Brebes, Wanasari, Jatibarang, dan Songgom. Sektor yang dapat dikembangkan adalah pertanian, khususnya subsektor perikanan, sektor perdagangan/jasa dan sektor pemerintahan.

b) SWP Ib, dengan pusat di Tanjung, meliputi Kecamatan Tanjung, Losari dan Bulakamba. Sektor yang dapat dikembangkan adalah sektor perdagangan dan pertanian.

c) SWP II, dengan pusat di Ketanggungan, meliputi Kecamatan Ketanggungan, Banjarharjo, Larangan dan Kersana. Sektor yang dapat dikembangkan di wilayah ini adalah sektor pertanian khususnya subsektor tanaman pangan antara lain meliputi sayur mayur, bawang merah dan lombok serta sektor pemerintahan.

SWP III, dengan pusat di Bumiayu, meliputi Kecamatan Bumiayu, Tonjong, Sirampog, Paguyangan, Bantarkawung dan Salem. Sektor yang dikembangkan adalah sektor pertanian, industri kecil, pariwisata, dan perdagangan.

Efisiensi merupakan tindakan memaksimalkan hasil dengan menggunakan modal (tenaga kerja, material dan alat) yang minimal (Banker and Cooper, 1984; Bowlin, 1996). Efisiensi merupakan rasio antara input dan output, dan perbandingan antara masukan dan pengeluaran. Apa saja yang dimaksudkan dengan masukan serta bagaimana angka perbandingan tersebut diperoleh, akan tergantung dari tujuan penggunaan tolok ukur tersebut. Secara sederhana, menurut Talluri (2000) efisiensi dapat berarti tidak adanya pemborosan.

Efisiensi dapat diestimasi dengan teknik analisis Data Envelopment Analysis (DEA) yang memiliki karakter berbeda dengan konsep efisiensi pada umumnya (yang diestimasi dengan pendekatan parametrik). Ada beberapa alasan mengapa alat analisis $D E A$ dapat dipakai untuk mengukur efisiensi suatu proses produksi yaitu: (1) efisiensi yangdiukur adalah bersifat teknis, bukan ekonomis. Hal ini dimaksudkan bahwa, analisis DEA hanya memperhitungkan nilai absolut dari suatu variabel. Satuan dasar pengukuran yang mencerminkan nilai ekonomis dari tiap-tiap variabel seperti harga, berat, panjang, isi dan lainnya tidak dipertimbangkan. Oleh karenanya dimungkinkan suatu pola perhitungan kombinasi berbagai variabel dengan satuan yang berbeda-beda; (2) nilai efisiensi yang dihasilkan bersifat relatif atau hanya berlaku dalam lingkup sekumpulan UKE (Unit Kegiatan Ekonomi) yang diperbandingkan (Talluri, 2000). Selanjutnya efisiensi untuk mengukur kinerja proses produksi dalam arti yang luas dengan mengoperasionalkan variabel-variabel yang mempunyai satuan yang berbeda-beda, yang kebanyakannya seperti dalam pengukuran barang-barang publik atau barang yang tidak mempunyai pasar tertentu (non-traded goods) maka alat analisis DEA merupakan pilihan yang paling sesuai (Cooper and Tone, 2002)

Data Envelopment Analysis (DEA) merupakan sebuah pendekatan non parametrik yang pada dasarnya merupakan teknik berbasis linier programming. DEA bekerja dengan langkah mengidentifikasi unit-unit yang akan dievaluasi, input serta output unit tersebut. Kemudian menghitung nilai produktivitas dan mengidentifikasi unit mana yang tidak menggunakan input secara efisien atau tidak menghasilkan ouput secara efektif. Produktivitas yang diukur bersifat komparatif atau relatif karena hanya membandingkan antar unit pengukuran dari 1 set data yang sama. 


\section{Jurnal Ekonomi Pembangunan, 15 (2), Desember 2014, 117-127}

Dalam penelitian ini analisis $D E A$ ditujukan untuk mengukur efisiensi PBM (memfokuskan pada identifikasi penambahan output yang diperlukan untuk mencapai kondisi DEA dengan mempertahankan input yang dimiliki saat ini).

Pada gambar 1 titik A menunjukkan efisiensi teknik tetapi pada titik A' jika menggunakan kombinasi input untuk memproduksi output yang sama, maka akan terjadi inefisiensi teknik karena menggunakan lebih banyak input dari yang dibutuhkan pada tingkat ouput efisiensi frontier. Titik B efisiensi teknik tetapi tidak efisien biaya karena pada tingkat ourput yang sama dapat memproduksi kurang dari biaya pada point C. Jika suatu organisasi bergerak dari titik A ke titik $\mathrm{C}$ efisiensi biaya akan meningkat (OA' - OA")/ OA'. Hal ini akan memperbaiki pengukuran efisiensi pada (OA' $\mathrm{OA})$ / OA dan efisiensi harga meningkat pada (OA - OA") / OA. Efisiensi teknik biasanya diukur dengan melihat apakah input perlu dikurangi secara proporsional untuk mencapai batas. Ini dikenal dengan nama konstrak radial input karena titik operasinya bergerak sepanjang garis dari titik origin sampai di mana organisasi berada.

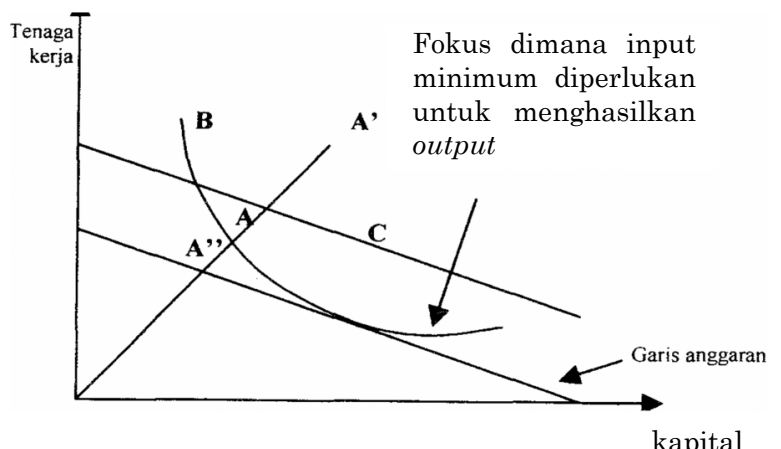

Gambar 1. Konsep Efisiensi

Menurut Cooper et al. (2000) suatu perusahaan akan dapat dikatakan efisien apabila: (1) Mempergunakan jumlah unit input yang lebih sedikit dibandingkan jumlah unit input yang digunakan oleh perusahaan lain dengan menghasilkan jumlah output yang sama, (2) Menggunakan jumlah unit input yang sama, tetapi dapat menghasilkan jumlah output yang lebih besar.

$$
\text { Maksimisasi } \rightarrow h_{s}=\frac{\sum_{r=1}^{m} u_{r k} y_{r k}}{\sum_{i=1}^{n} v_{r k} x_{r k}}
$$

di mana, $\boldsymbol{h} \boldsymbol{s}$ adalah efisiensi teknik obyek $\boldsymbol{s}, \boldsymbol{m}$ adalah output obyek yang diamati, $\boldsymbol{n}$ adalah input obyek yang diamati, $\mathrm{y}_{\mathbf{r k}}$ merupakan jumlah output $\boldsymbol{r}$ yang diproduksi oleh obyek $\boldsymbol{k}$, $\mathbf{x}_{\mathbf{r k}}$ adalah jumlah input $\boldsymbol{r}$ yang digunakan oleh obyek $\boldsymbol{k}, \mathbf{u}_{\mathrm{rk}}$ merupakan bobot output $\boldsymbol{r}$ yang dihasilkan oleh obyek $\boldsymbol{k}$, vrk adalah bobot input $\boldsymbol{r}$ yang diberikan oleh obyek $\boldsymbol{k}$, dan $\boldsymbol{r}$ dihitung dari 1 ke $m$ serta $i$ ihitung dari 1 ke $n$.

Persamaan di atas menunjukkan adanya penggunaan satu variabel input dan satu output. Rasio efisiensi (hs), kemudian dimaksimalkan dengan kendala sebagai berikut (Talluri et al., 1997):

$$
\frac{\sum_{r=1}^{m} u_{r j} Y_{r j}}{\sum_{r=1}^{n} v_{i k} X_{i j}} \leq 1 ; \mathrm{j}=1, \ldots, \mathrm{N}
$$

Kriteria non-negatif,

$\mathrm{u}_{\mathrm{rk}} \geq 0 ; \mathrm{r}=1, \ldots, m$

$\mathrm{Vrk}_{\mathrm{rk}} \geq 0 ; 1=1, \ldots, n$

di mana, $\mathbf{N}$ menunjukkan jumlah obyek dalam sampel. Pertidaksamaan pertama menunjukkan adanya efisiensi rasio untuk UKE lain tidak lebih dari 1 , sementara pertidaksamaan kedua berbobot positif. Angka rasio akan bervariasi antara 0 sampai dengan 1 . Obyek dikatakan efisien apabila memiliki angka rasio mendekati 1 atau 100 persen, sebaliknya jika mendekati 0 menunjukkan efisiensi obyek yang semakin rendah.

Beberapa bagian program linier ditransformasikan ke dalam program ordinary linier secara primal sebagai berikut (Cooper et al., 2000; Talluri et al., 1997):

Fungsi Tujuan:

(DEA) Maksimumkan hk $=\sum_{r=1}^{s} u_{y k} Y_{r k}$ $\left[p_{k j} \sum_{r=1}^{s} u_{r k} y_{r k}-\sum_{i=1}^{m} v_{i k} X_{i j k} \leq 0 ; j=1, \ldots \ldots . . N\right.$ 


\section{Jurnal Ekonomi Pembangunan, 15 (2), Desember 2014, 117-127}

$\left[q_{k j} \sum_{i=1}^{m} v_{i k} X_{i j k}=1\right.$ di mana $\mathrm{u}_{\mathrm{rk}}$ dan $\mathrm{v}_{\mathrm{rk}} \geq 0$

Efisiensi pada masing-masing input dihitung menggunakan programasi linier dengan memaksimumkan jumlah output yang dibobot dari obyek $k$. Kendala jumlah input yang dibobot harus sama dengan satu untuk obyek $k$, sedangkan kendala untuk semua obyek, yaitu jumlah output yang dibobot dikurangi jumlah input yang dibobot harus kurang atau sama dengan 0. Hal ini berarti semua obyek akan berada atau di bawah referensi kinerja frontier yang merupakan garis lurus yang memotong sumbu origin (Purwantoro, 2003).

Dalam $D E A$, efisiensi dinyatakan dalam rasio antara total input tertimbang. Dimana setiap UKE diasumsikan bebas menentukan bobot untuk setiap variabel-variabel input maupun variabel output yang ada, asalkan mampu memenuhi dua kondisi yang disyaratkan yaitu (Cooper et al., 2000):

(a) Bobot tidak boleh negatif, (b) Bobot harus bersifat universal atau tidak menghasilkan indikator efisiensi yang di atas normal atau lebih besar dari nilai 1 bilamana dipakai UKE yang lainnya.

Dalam rangka mencapai tingkat efisiensi yang maksimal, maka setiap UKE cenderung memiliki pola untuk menetapkan bobot tinggi pada input yang sedikit digunakan, dan pada output yang banyak dihasilkan. Di mana bobot yang dipilih tersebut tidak semata-mata menggambarkan suatu nilai ekonomis, tetapi lebih merupakan suatu kuantitatif rencana untuk memaksimalkan efisiensi UKE bersangkutan. Suatu UKE dikatakan efisien secara relatif, bilamana nilai dualnya sama dengan 1 (nilai efisiensi $=100 \%$ ). Sebaliknya bila nilai dualnya kurang dari 1, maka UKE bersangkutan dianggap tidak efisien secara relatif (Hadad et al., 2003).

\section{Metode Penelitian}

Pengambilan sampel dalam penelitian ini menggunakan teknik purposive sampling, yaitu pengambilan sampel non-probabilitas yang disesuaikan dengan tujuan penelitian. Populasi penelitian ini adalah seluruh petani bawang merah di Kabupaten Brebes. Sedang- kan sampel yang akan diambil dalam penelitian ini adalah 30 petani bawang merah di Kabupaten Brebes, yang bermukim di enam (6) Desa, yaitu Luwungragi, Siwuluh, Banjaratma, Petunjungan, Tegalglagah dan Sitanggal. Masing-masing Desa diambil 5 petani sebagai sampel penelitian ini.

Data yang dipergunakan terdiri atas data primer dan data sekunder. Data primer diperoleh dari hasil wawancara mendalam terhadap 20 responden petani di 5 desa di kecamatan Bulakamba Kabupaten Brebes, yaitu desa Luwungragi, desa Siwuluh, desa Banjaratma, desa Tunjungan dan desa Sitanggal. Setiap desa masing-masing diambil dua (2) responden. Data sekunder diperoleh dari Departemen Pertanian, Dinas Pertanian Tanaman Pangan Holtikultura Brebes dan Bappeda Kabupaten Brebes

Sekaran (2006); Jogiyanto (2003) menyatakan bahwa pengoperasionalan konsep (operationalizing the concept) atau disebut dengan mendefinisikan konsep secara operasi adalah menjelaskan karakteristik dari obyek (properti) kedalam elemen-elemen (elements) yang dapat diobservasi yang menyebabkan konsep dapat diukur dan dioperasionalkan di dalam riset. Konsep secara operasi yang perlu didefiniskan adalam penelitian ini adalah:

(a) Ouput adalah jumlah produksi bawang merah per-hektar dalam satu tahun (dua kali tanam) yang diukur menggunakan kilogram (kg) dan nilai nominal (Rupiah)

(b) Input adalah pengeluaran (biaya) yang dibutuhkan untuk memproduksi bawang merah per-hektar dalam satu tahun (dua kali tanam) yang diukur menggunakan nilai nominal (Rupiah).

Perhitungan analisis efisiensi usahatani di daerah penelitian dengan menggunakan Data Envelopment Analysis (DEA), dengan memasukkan 7 variabel input yaitu: (i) bibit, (ii) pupuk buatan, (iii) pupuk lain-nya, (iv) pestisida, (v) obat lain-nya, (vi) tenaga kerja, dan (vii) biaya lain-nya. Sedangkan variabel outputnya terdiri dari jumlah produksi $(\mathrm{kg})$ atau nilai produksi (Rp.).

Analisis struktur profitabilitas usahatani bawang merah akan melihat seberapa besar pendapatan usahatani dan produksi yang dihasilkan petani. Analisis ini menggunakan 


\section{Jurnal Ekonomi Pembangunan, 15 (2), Desember 2014, 117-127}

analisis biaya dan pendapatan dengan rumus;

$\pi=T R-T C$

di mana, $\Pi$ adalah Pendapatan petani dari usahatani bawang merah, TR adalah Total penerimaan dari usahatani bawang merah, TC adalah Total pengeluaran pada usahatani bawang merah.

Selanjutnya untuk menganalis kinerja margin pemasaran usaha tani, digunakan data harga di tingkat petani dan harga di tingkat lembaga pemasaran, sehingga dalam perhitungan margin pemasaran digunakan formula:

$\mathrm{Mm}=\mathrm{Pe}-\mathrm{Pf}$

dimana, Mm adalah margin pemasaran di tingkat petani, Pe adalah harga di tingkat kelembagaan pemasaran tujuan pemasaran petani, Pf adalah harga di tingkat petani.

Bagian harga yang diterima petani (farmer's share) merupakan perbandingan harga yang diterima oleh petani dengan harga di tingkat lembaga pemasaran yang dinyatakan dalam persentase. Farmer's share diformulasikan sebagai berikut:

$F s=\frac{P f}{\operatorname{Pr}} \times 100 \%$

di mana, Fs adalah farmer's share, Pf adalah harga di tingkat petani, Pr adalah harga di tingkat lembaga pemasaran.

\section{Hasil Analisis dan Pembahasan}

Tabel 2 menunjukkan hasil analisis profitabilitas usahatani bawang merah dilokasi penelitian. Produksi bawang merah ha-1 dalam dua kali tanam dalam setahun cukup besar yaitu 11,13564 ton $(11.135,64 \mathrm{~kg})$ dengan nilai penerimaan (revenue) produksi sebesar Rp69.976.500. Sedangkan keuntungan bersih setelah dikurangi berbagai pengeluaran (biaya produksi) sebesar Rp4.670.114, dengan $\mathrm{R} / \mathrm{C}$ rasio sebesar 1,1 .

Berdasarkan hasil analisis ini dapat disimpulkan bahwa ber-usahatani bawang merah telah dapat memberikan keuntungan bagi petani, namun keutungan yang diperoleh terhitung sangat kecil jika dibandingkan dengan biaya produksi yang telah dikeluarkan. Hal ini sesuai dengan hasil pengamatan (interview in depth) peneliti di lapangan terhadap petani yang menyatakan bahwa tingkat keuntungan yang diperoleh belum cukup untuk memenuhi kebutuhan ekonomi rumah tangga petani. Atau dengan kalimat lain, usahatani bawang merah dilokasi penelitian tidak memberikan keuntungan yang siginfikan (unprofitable) terhadap ekonomi rumah tangga petani. Keuntungan yang kecil itu disebabkan oleh tingkat biaya produksi yang telalu tinggi, yaitu mencapai 90 persen dari total revenue. Biaya produksi tertinggi dikeluarkan untuk upah tenaga kerja yang mencapai 52,26 persen, kemudian diikuti secara ber-urutan yaitu bibit 22,81 persen, pupuk 10,01 persen, pestisida 10,00 persen dan biaya lain-nya 4,82 persen.

Tabel 2. Analisis Profitabilitas Usahatani Bawang Merah di Kabupaten Brebes, 2013

\begin{tabular}{|c|c|c|}
\hline & Uraian & Nilai (Rp.) \\
\hline \multirow[t]{3}{*}{ A. } & Penerimaan & \\
\hline & (1) Produksi (kg) & $11.135,64$ \\
\hline & (2) Nilai (Rp) & 69.976 .500 \\
\hline \multirow[t]{11}{*}{$\mathrm{B}$} & \multicolumn{2}{|l|}{ Pengeluaran } \\
\hline & (1) Bibit & 14.894 .776 \\
\hline & Pupuk buatan & 4.165 .750 \\
\hline & Pupuk lain-nya & 2.420 .550 \\
\hline & Pestisida & 4.650 .224 \\
\hline & Obat lain-nya & 1.894 .450 \\
\hline & \multicolumn{2}{|l|}{ (6) Tenaga kerja } \\
\hline & (i) Dalam keluarga & 5.865 .400 \\
\hline & (ii) Luar Keluarga & 28.266 .136 \\
\hline & (7) Biaya lain-nya & 3.149 .100 \\
\hline & Total Pengeluaran & 65.306 .386 \\
\hline $\mathrm{C}$ & Keuntungan & 4.670 .114 \\
\hline $\mathrm{D}$ & $\mathrm{R} / \mathrm{C}$ & 1,1 \\
\hline
\end{tabular}

Sumber: Data Diolah

Tabel 3 menunjukkan hasil analisis bagian harga yang diterima petani (farmer's share). Hasil analisis ini menunjukkan bahwa bagian harga jual yang diterima pada berbagai kelembagaan pasar mulai dari tingkat petani sampai dengan pasar eceran berkisar antara Rp4.000 sampai dengan Rp7.390. Berdasarkan harga jual ini terlihat bahwa perbedaan antara harga di tingkat petani dengan tujuan kelembagaan pemasaran, paling tinggi terjadi pada tingkat supermarket (Rp10.500), berikutnya dengan pasar di tingkat pengecer (Rp7.065 Rp7.390) dan pasar induk Klampok, pedagang 


\section{Jurnal Ekonomi Pembangunan, 15 (2), Desember 2014, 117-127}

besar, serta pasar induk Kramatjati (Rp5.275 Rp6.340). Sedangkan farmer's share terhadap berbagai tingkat lembaga pemasaran diperoleh share secara berurutan yaitu: pedagang pengumpul 81,63 persen, pasar induk Klampok Brebes 75,83 persen, pedagang besar 66,06 persen, pedagang pasar induk Kramatjati 63,09 persen, pedagang pengecer pasar induk Kramatjati 56,62 persen, pasar eceran 54,13 persen dan supermarket 38,10 persen. Berdasarkan share ini dapat disimpulkan bahwa harga jual yang cukup tinggi di tingkat pengecer dan supermarket tidak tertransmisikan dengan baik ke tingkat petani, sehingga petani tetap memperoleh farmer's share yang kecil dan berfluktuasi. Atau dengan dengan kalimat lain, tingginya harga jual di tingkat pengecer dan supermarket tidak berdampak signifikan terhadap tingkat keuntungan usahatani di lokasi penelitian.

Tabel 3. The farmer's share oleh berbagai kelembagaan pemasaran bawang Mira, 2008

\begin{tabular}{lcc}
\hline Tujuan Pemasaran & $\begin{array}{l}\text { Harga } \\
\left(\mathrm{Rp} \mathrm{kg}^{-1}\right)\end{array}$ & Persen \\
\hline 1. Harga jual di tingkat & 4.000 & - \\
petani & & \\
2. Harga jual di pedagang & 4.900 & 81,63 \\
$\begin{array}{l}\text { pengumpul } \\
\text { 3. Harga jual di pasar } \\
\text { induk Klampok-Brebes }\end{array}$ & 5.275 & 75,83 \\
4. Harga jual di pedagang \\
$\begin{array}{l}\text { besar } \\
\text { 5. } \begin{array}{l}\text { Harga jual di pedagang } \\
\text { pasar induk Kramatjati }\end{array}\end{array}$ & 6.055 & 66,06 \\
6. Harga jual di pedagang \\
$\begin{array}{l}\text { pengecer pasar induk } \\
\text { (Kramatjati) }\end{array}$ & 7.065 & 63,09 \\
7. Harga jual di pasar & 7.390 & 54,62 \\
$\begin{array}{l}\text { eceran } \\
\text { 8. Supermarket }\end{array}$ & 10.500 & 38,10 \\
\hline
\end{tabular}

Sumber: Data Diolah

Tabel 3 menunjukkan hasil analisis margin pemasaran bawang merah pada petani untuk berbagai tujuan pemasaran. Perolehan margin pemasaran komoditas bawang merah pada petani terendah diperoleh untuk tujuan pedagang pengumpul dengan margin yang diperoleh sebesar Rp900, kemudian untuk tujuan pemasaran pedagang pasar induk Klampok dan pedagang besar secara berurutan marjinnya sebesar Rp1.275 dan Rp2.055.
Tabel 4. Margin pemasaran bawang merah pada petani untuk berbagai tujuan pemasaran, 2008

\begin{tabular}{lcc}
\hline Tujuan Pemasaran & $\begin{array}{l}\text { Harga Jual } \\
\left(\mathrm{Rp} \mathrm{kg}^{-1}\right)\end{array}$ & $\begin{array}{l}\text { Margin } \\
\text { Pemasaran } \\
\left(\mathrm{Rp} \mathrm{kg}^{-1}\right)\end{array}$ \\
\hline 1. $\begin{array}{l}\text { Pedagang } \\
\text { pengumpul }\end{array}$ & 4.900 & 900 \\
2. $\begin{array}{l}\text { Pedagang pasar } \\
\text { induk (Klampok) }\end{array}$ & 5.275 & 1.275 \\
3. $\begin{array}{l}\text { Harga jual di } \\
\text { pedagang besar }\end{array}$ & 6.055 & 2.055 \\
\hline
\end{tabular}

Sumber: Data Diolah

Tabel 4 menunjukkan hasil analisis efisiensi dengan indikator skor efisiensi untuk masing-masing desa yang diobservasi. Berdasarkan hasil estimasi dengan menggunakan alat bantu analisis Banxia Frontier Analysis dapat ditemukan skor efisiensi untuk masingmasing desa yang terpilih sebagai lokasi observasi (penelitian). Skor efisiensi untuk Desa Luwungragi 65,54 persen; Desa Siwuluh 64,63 persen; Desa Banjaratma 63,76 persen; Desa Petunjungan 64,05 persen; Tegalglagah 66,06 persen dan Desa Sitanggal 65,00 persen, sehinngga rata-rata skor efisiensi dari ke-enam Desa tersebut sebesar 64,84 persen. Berdasarkan skor rata-rata efisiensi dapat disimpulkan bahwa usahatani yang dilakukan oleh petani di lokasi penelitian tidak efisien, karena skor efisiensinya kurang dari 100 persen.

Tabel 5. Skor efisiensi usahatani, 2008

\begin{tabular}{llcc}
\hline No & $\begin{array}{l}\text { Usahatani } \\
\text { di Desa }\end{array}$ & $\begin{array}{l}\text { Skor Efisiensi } \\
\text { (Persian) }\end{array}$ & Keterangan \\
\hline 1 & Luwungragi & 65,54 & inefisien \\
2 & Siwuluh & 64,63 & inefisien \\
3 & Banjaratma & 63,76 & inefisien \\
4 & Petunjungan & 64,05 & inefisien \\
5 & Tegalglagah & 66,06 & inefisien \\
6 & Sitanggal & 65,00 & inefisien \\
\hline
\end{tabular}

Sumber: Perhitungan DEA dengan Banxia Frontier Analysis, 2008

Tabel 5 menunjukkan potensi peningkatan efisiensi usahatani bawang merah di lokasi penelitian. Potensi pengembangan (potential improvement) input dilihat secara negatif sedangkan untuk output dilihat secara positif. Untuk meningkatkan efisiensi sampai batas efficient frontier secara teoritis usahatani bawang merah di lokasi penelitian cukup 


\section{Jurnal Ekonomi Pembangunan, 15 (2), Desember 2014, 117-127}

dengan membelanjakan pupuk buatan sebesar Rp2.905.194 atau 30,26 persen lebih kecil dari belanja pupuk buatan sebenar-nya, demikian juga dengan pupuk lain-nya dikurangi menjadi sebesar 1.925.548 atau 20,45 persen dari belanja pupuk lain-nya yang aktual. Sedangkan untuk belanja pestisida dikurangi menjadi sebasar Rp2.319.532 atau 50,12 persen lebih sedikit dari belanja pestisida yang aktual atau dengan kalimat lain, pembelanjaan pestisida yang dilakukan oleh petani selama ini sudah terlalu tinggi atau terjadi pemborosan penggunaan pestisida sehingga perlu rasionalisasikan sebesar 50,12 persen, demikian juga dengan obat lain-nya perlu rasionalisasikan sebesar 40,25 persen. Sementara untuk tenaga kerja untuk mencapai batas efficient frontier diperlukan pengurangan tenaga kerja luar keluarga, sehingga pembiayaan untuk tenaga kerja cukup dengan pengeluaran sebesar Rp25.905.914 atau 8,35 persen lebih kecil dari pembiayaan tenaga kerja dalam sesungguhnya. Atau dengan kalimat lain, tenaga kerja yang selama ini dipekerjakan oleh petani terlau banyak sehingga perlu untuk dirasionalisasikan sebesar 8,35 persen, demikian juga dengan tenaga kerja dalam perlu dirasionalisasikan sebesar 6,45 persen. Sementara untuk biaya lain-nya juga perlu dikurangi sebesar 15,45 persen.

Di sisi lain untuk output, agar mencapai batas efficient frontier diperlukan penigkatan produksi bawang merah menjadi $17.260,242 \mathrm{~kg}$ (17,260 ton) ha-1 dengan nilai penerimaan sebesar Rp108.463.5751 dalam dua kali tanam atau 55 persen lebih besar dari produksi sudah yang terjadi.

Hasil penelitian ini mendukung penelitian yang dilakukan oleh Nurasa dan Darwis (2007) yang menyatakan bahwa menurut petani, pendapatan usahatani bawang merah yang diterimanya selalu berfluktuasi. Hal ini antara lain dipengaruhi oleh penurunan perolehan produksi yang diakibatkan oleh fluktuasi harga obat-obatan (55,56 persen) karena petani terbiasa banyak melakukan penyemprotan dengan menggunakan obat-abatan kimia yang harganya dirasa semakin mahal dan juga adanya obat-obatan yang dirasakan tidak efektif karena kemungkinan palsu. Pengaruh terbesar kedua adalah karena pengaruh keadaan iklim terutama di saat musim kemarau/ kering (50 persen) di mana kita ketahui tanaman bawang merah sangat ketergantungan akan kecukupan air. Penyebab lainnya berkurangnya keuntungan yang diterima disebabkan oleh fluktuasi harga output, harga bibit, dan harga pupuk (masing-masing 33,3, 33,33 , dan 28,57 persen).

\section{Simpulan}

Untuk mencapai tujuan yang sudah dipaparkan dalam penelitian ini, diperlukan langkahlangkah strategis yaitu mendesain (menyusun) metode penelitian, mengolah data dan menganalisis hasil serta pembahasannya, sehingga sampai pada beberapa poin simpulan bahwa usahatani bawang merah di lokasi penelitian tidak memberikan keuntungan yang siginfikan (unprofitable) terhadap ekonomi rumah tangga petani; harga jual yang cukup tinggi di tingkat

Tabel 5. Potensi pengembangan usahatani bawang merah dilihat dari input atau output

\begin{tabular}{|c|c|c|c|c|}
\hline Input/Output & Uraian & Nilai Aktual (Rp) & Nilai Target (Rp) & Potential Improvement \\
\hline \multirow{9}{*}{ Input } & (1) Bibit & 14.894 .776 & 14.894 .776 & $00,00 \%$ \\
\hline & (2) Pupuk buatan & 4.165 .750 & 2.905.194 & $-30,26 \%$ \\
\hline & (3) Pupuk lain-nya & 2.420 .550 & 1.925 .548 & $-20,45 \%$ \\
\hline & (4) Pestisida & 4.650 .224 & 2.319 .532 & $-50,12 \%$ \\
\hline & (5) Obat lain-nya & 1.894 .450 & 1.131.934 & $-40,25 \%$ \\
\hline & (6) Tenaga kerja & & & \\
\hline & (i) Dalam keluarga & 5.865 .400 & 5.487 .082 & $-6,45 \%$ \\
\hline & (ii) Luar keluarga & 28.266.136 & 25.905 .914 & $-8,35 \%$ \\
\hline & (7) Biaya lain-nya & 3.149 .100 & 2.662 .564 & $-15,45 \%$ \\
\hline \multirow{2}{*}{ Output } & (1) Produksi (kg) & $11.135,64$ & $17.260,242$ & $55 \%$ \\
\hline & (2) Nilai (Rp) & 69.976 .500 & 108.463 .575 & $55 \%$ \\
\hline
\end{tabular}

Sumber: Perhitungan DEA dengan Banxia Frontier Analysis, 2008 


\section{Jurnal Ekonomi Pembangunan, 15 (2), Desember 2014, 117-127}

pengecer dan supermarket tidak tertransmisikan dengan baik ke tingkat petani, sehingga petani tetap memperoleh farmer's share yang kecil dan berfluktuasi; perolehan margin pemasaran komoditas bawang merah pada petani terendah diperoleh untuk tujuan pedagang pengumpul dengan margin yang diperoleh sebesar Rp900, serta usahatani yang dilakukan oleh petani di lokasi penelitian tidak efisien, karena skor efisiensinya kurang dari 100 persen.

Pemerintah Kabupaten disarankan untuk melakukan kebijakan-kebijakan yang mengarah pada penguatan kelembagaan kemitraan usaha komoditas bawang merah dengan visi "Mencapai Indonesia Sebagai Eksportir Bawang Merah"; Pemerintah Kabupaten dapat mewujudkan: (a) tersedianya varietas baru yang produktif, adaptif dan tahan terhadap hama/penyakit, (b) tersedianya teknologi produksi dan pengelolaan benih bermutu, konsep jaminan dan standarisasi mutu sebagai langkah awal untuk membangun industri benih nasional yang tangguh dan mandiri; (c) Tersedianya teknologi budidaya yang ramah lingkungan dan efisien dengan memanfaatkan sumberdaya lokal secara optimal dan berkelanjutan untuk menghasilkan produk hortikultura modern dan efisien sekaligus membuka peluang munculnya industri sarana penunjang di berbagai daerah; (d) Tersedianya teknologi pengendalian hama/penyakit yang berbasis pada penggunaan musuh alami dan pengurangan pestisida sintetis serendah mungkin; (e) Tersedianya teknologi pasca panen untuk efisiensi pengemasan, konservasi mutu segar, diversifikasi produk yang berkaitan dengan peningkatan nilai tambah industri hortikultura. Serta Peng-usahatani, melakukan langkah-langkah efisiensi terhadap penggunaan pestisida, pupuk, dan tenaga kerja serta melakukan langkah-langkah untuk meningkatkan produksi bawang merah dengan cara penggunaan bibit unggul dan dan tahan tehadap hama, serta penggunaan teknologi produksi dan pengelolaan benih yang bermutu tinggi.

Beberapa keterbatasan dalam metode penelitian ini adalah lama pengamatan (observasi) dilakukan hanya dalam satu periode yaitu tahun 2008; Pengamatan dilakukan hanya pada enam lokasi penelitian, yaitu desa yang dipandang sebagai penghasil bawang merah terbesar di Kabupaten Brebes; Hasil analisis profitabilitas tidak memasukan kemungkinan biaya sewa lahan bagi petani yang menyewa lahan garapan bawang merah dan nnalisis efisiensi dalam penelitian ini lebih menitikberatkan pada konsep efisiensi harga (allocative or price efficiency).

Saran yang bisa dilakukan untuk penyempurnaan penelitian ini, bagi peneliti berikutnya adalah untuk mendapatkan hasil penelitian dengan tingkat keakurasian yang lebih tinggi diperlukan penambahan lama periode pengamatan, misalnya lima tahun terakhir; untuk menghindari adanya pembiasan hasil pengolahan data, diperlukan penambahan lokasi pengamatan; dalam usahatani bawang merah, banyak petani yang tidak menggunakan tanah sawahnya sendiri, tetapi menyewa tanah orang lain, sehingga perlu dimasukkan unsur biaya sewa tanah dalam analisis profitabilitas dan efisiensi serta unuk mendapatkan hasil yang lebih baik perlu dipertimbangkan penambahan analisis efisiensi teknik (technical analysis).

\section{Daftar Pustaka}

Adiyoga, W. 2000. Perkembangan ekspor-Impor dan ketidakstabilan penerimaan ekspor komoditas sayuran di Indonesia. Jurnal Hortikultura. Vol 10 (1): 70-81.

Agustian, A., Zulham, A., Syahyuti, Tarigan, H., Supriatna, A., Supriyatna, Y., Nurasa, T. 2005. Analisis berbagai bentuk kelembagaan pemasaran dan dampaknya terhadap peningkatan usaha komoditas pertanian. laporan akhir penelitian. PSEKP-Badan Penelitian dan Pengembangan Pertanian, Jakarta: Departemen Pertanian

Andersen, P., \& Petersen, N. C. 1993. A procedure for ranking efficient units in data envelopment analysis. Management Science, 39(10), 1261-1264.

Banker, R. D., Chames, A, \& Cooper, W. W. 1984. Some models for estimating technical and scale inefficiencies in data envelopment analysis. Management Science, 30(9), 1078-1092. 


\section{Jurnal Ekonomi Pembangunan, 15 (2), Desember 2014, 117-127}

Budiarto, Joko. 2004. Dukungan teknologi bagi pengembangan hortikultura tahun 2003. Jakarta: Badan Penelitian dan Pengembangan Pertanian.

Bappeda Brebes. 2005, Produk unggulan pertanian di kabupaten Brebes. $w w w$. brebeskab.go.id

BPS Brebes. 2008. Kabupaten Brebes dalam angka tahun 2008. Brebes: Badan Pusat Statistik Kabupaten Brebes.

Bhat, R., Bharat, B., dan Elan Reuben. 1998, Methodology note: data envelopment analysis (DEA). India: IIM Ahmedabad

Bowlin, WF. 1996. Measuring performance: an introduction to data envelopment analysis (DEA), Journal of Cost Analysis, 3-7

Cooper, W.W., Seiford, L.M. and Kaoru Tone. 2002. Data envelopment analysis: a comprehensive text with models, applications, references and dea-solver software, $3^{\text {rd }}$ ed., Boston: Kluwer Academic

Gonarsyah, Isang. 1992. Peranan pasar induk kramat jati sebagai barometer harga sayur mayur di wilayah DKI Jakarta. Mimbar Sosek, Bogor: Institut Pertanian Bogor. (5):43-48.

Hadi, P.U., H. Mayrowani, Supriyati dan Sumedi 2000. Review and outlook pengembangan komoditas hortikultura. seminar nasional perspektif pembangunan perta-nian dan kehutanan tahun 2001 ke depan. Bogor Pusat Penelitian Sosial Ekonomi Pertanian. Badan Penelitian dan Pengembangan Pertanian,

Irawan, B., Simatupang P, Sugiarto, Supadi, Agustin, NK., Sinuraya, JF. 2006. Panel Petani Nasional (PATANAS): analisis indikator pembangunan pertanian dan pedesaan. Laporan Akhir Penelitian. PSEKP-Badan Penelitian dan Pengembangan Pertanian, Jakarta: Departemen Pertanian
Kuma'at, R. 1992. Sistem pemasaran sayuran dataran tinggi di provinsi Sulawesi Utara. Thesis MS - FPS IPB, Bogor.

Mubyarto. 1989. Pengantar ekonomi pertanian. Jakarta: LP3ES

Rachman, H.P.S. 1997. Aspek permintaan, penawaran dan tataniaga hortikultura di Indonesia. Forum Agro Ekonomi 15 (1 dan 2): 44-56. Laporan Akhir Pusat Penelitian dan Pengembangan Sosial Ekonomi Pertanian. Badan Penelitian dan Pengembangan Pertanian, Bogor.

Nurasa, T., dan Darwis, V. 2007, Analisis usahatani dan keragaan marjin pemasaran bawang merah di kabupaten Brebes". Jurnal Akta Agrosia, Vol. 10 No.1 h. 40-48

Saptana, Indraningsih, K.C. dan Hastuti, E.L. 2006. Analisis kelembagaan kemitraan usaha di sentra-sentra produksi sayuran". Bogor: Pusat Analisis Sosial Ekonomi dan Kebijakan Pertanian.

SudaryantoT., Y. Yusdja, A. Purwoto, K.M. Noekman, A. Bwariyadi, dan W.H. Limbang. 1993. Agribisnis komoditas hortikultura. Laporan Akhir Pusat Penelitian dan Pengembangan Sosial

Talluri, S. 2000. Data envelopment analysis: models and extensions. International Journal of Flexible Manufacturing System

Thamrin, M., Ramlan, Armiati, Ruchjaningsih dan Wahdania. 2003. Pengkajian sistem usahatani bawang merah di Sulawesi Selatan. Jurnal Pengkajian dan Pengembangan Teknologi Pertanian Vol. 6, No. 2: $141-153$ 